\section{Acta Hydrobiologica et Protistologica}

A NEW international review on hydrobiology and protistology is to appear shortly, under the above title. The board of editors comprises Dr. G. Alm (Sweden), Prof. H. d'Ancona (Italy), Prof. K. Berg (Denmark), Prof. F. F. Fritsch (Great Britain), Prof. K. Münster Ström (Norway), Prof. William R. Taylor (United States), Mrs. N. Wibaut-Isebree Moens (Holland), Prof. P. van Oye (Belgium), managing secretary. Some seventy leading scientific workers from most countries of the world have promised to support the new periodical, which is intended not only for the publication of original papers on all branches of hydrobiology and protistology, but also for reviews of books and papers, information on scientific institutes, along with a personal section, correspondence, etc. The review is to appear in four quarterly issues of about 100 pages each; the price of each volume of four issues will be 40 guilders. Subscriptions should be sent to A. Oosthoek's Uitgevers Mij, Domstraat 1-3, Utrecht, Holland.

\section{Britain in 1955}

"BRITAIN IN 1955" is the theme of a special issue of Future, skilfully and collectively produced by a group of experts. 'The 'high light' is an economic analysis, from the vantage point of 1955, of the preceding decade; but other articles, particularly on the agricultural revolution, industrial relations, the universities, and meteorology, are also most stimulating. In effect, the future is foreshadowed by an informed examination, on specified assumptions, of current trends. A synoptic approach is adopted throughout. There are touches of "The Shape of Things to Come", "Erewhon", and "Brave New World" in judicious combination. An unreal element is the apparent disappearance of serious political controversy. Is this wishful thinking ?

\section{U.S. National Research Council Fellowships}

THE U.S. National Research Council is again offering a number of fellowships for advanced study and research in the natural sciences. The postdoctoral fellowship programme, administered by the Council for the past twenty-eight years and financed by grants from the Rockefeller Foundation, is designed to permit young men and women who have demonstrated their ability in research in the natural sciences to spend additional time in uninterrupted study. Stipends are at the rate of 2,500 dollars a year, plus travel to the place of study. Since the War, Merck and Co. has supported a fellowship programme in the chemical and biological sciences, designed to stimulate interest in fields of study requiring knowledge of more than one science. These fellowships are therefore designed to give special training to young men and women who have demonstrated marked ability in research in chemical or biological science and who wish to broaden their fields of investigational activity. The annual stipends are in the range 2,500-5,000 dollars, with an allowance of 500 dollars a year to the institution to which each fellow is assigned. A third programme recently inaugurated by the Radio Corporation of America is designed to give special training and experience to young men and women who have demonstrated marked ability in the general field of electronics. Their preliminary experience may have been either in the fields of electrical engineering or physics. Applicants need not have completed more than one year of graduate work, and they must be United States citizens. The fields of study to be undertaken are in the sciences underlying the general science of electronics. Stipends range from 1,600 to 2,100 dollars a year. Further particulars of all these fellowships can be obtained from the National Research Council Fellowship Office, National Research Council, 2101 Constitution Avenue, N.W., Washington 25, D.C.

\section{University of London: Appointments}

THE following appointments in the University of London have been announced: Mr. W. D. Hogarth to be clerk of the University Court as from January 1 in succession to Dr. D. W. Logan, who becomes principal of the University on that date; Dr. L. P. Mair to the University readership in Colonial administration tenable at the London School of Economics and Political Science as from October 1; 1947; Dr. N. F. Maclagan to the University chair of chemical pathology tenable at Westminster Hospital Medical School as from October 1, 1947.

The degree of doctor of science has been conferred. on Conrad Ellenby, of University College, and on G. M. Dyson, an external student.

\section{The Botanical Society of the British Isles}

THE name of the Botanical Society and Exchange Club of the British Isles has been changed to the Botanical Society of the British Isles. New and extended facilities are being offered to members, including the privilege of consulting a panel of specialists. A Conference on "The Study of Critical British Groups" is being arranged in London during April 9-10, 1948. All inquiries should be addressed to the honorary general secretary, Miss M. S. Campbell, c/o Department of Botany, British Museum (Natural History), Cromwell Road, London, S.W.7.

\section{Commonwealth Agricultural Bureaux}

THE Executive Council of the Imperial Agricultural Bureaux has decided to change the name of the Bureaux as from January 1 to Commonwealth Agricultural Bureaux. The Bureaux will continue as hitherto in control of the Institute of Entomology, the Mycological Institute, the Bureaux of Soil Science, Animal Health, Animal Nutrition, Plant Breeding and Genetics, Pastures and Field Crops, Horticulture and Plantation Crops, Animal Breeding and Genetics, Agricultural Parasitology (Helminthology), Forestry, Dairy Science, Biological Control and the South American Potato Collection.

\section{Announcements}

THe Medical Research Council has recently reconstituted the Dental Research Committee, the function of which is to advise and assist them in the promotion of scientific investigations in this field. The secretary of the Committee is Prof. M. A. Rushton, Department of Dental Medicine, Guy's Hospital, London, S.E.1.

A SERIES of three Christmas Lectures for Boys, on "High-Speed Flying and the Airport", has been arranged by the Institution of Civil Engineers. They will be given by Group Captain E. M. Donaldson, C. E. Foster, and Air Marshal Sir John D'Albiac, on December 30 , January 2 and 6 , at 3 p.m. Tickets, which are free, can be obtained from the Secretary, Institution of Civil Engineers, Great George Street, Westminster, London, S.W.1. 